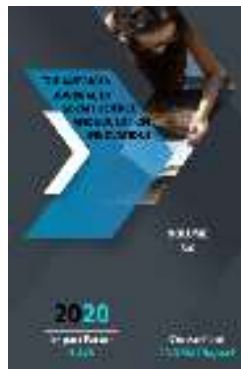

Journal Website: http://usajournalshub.c om/index,php/tajssei

Copyright: Original content from this work may be used under the terms of the creative commons attributes 4.0 licence.

\section{The Role Of The Dynasty Of Mahbubi In The Development Of Hanafi Fiqh (Islamic Jurisprudence) Mowarounnahr (XII- XIII Centuries)}

\author{
Abduvosi Abdumalikovich Ganiev \\ Deputy Director For Spiritual And Enlightenment Affairs “Kokaldosh” Secondary Special \\ Islamic School, Uzbekistan
}

\title{
ABSTRACT
}

After the independence of Uzbekistan, the attention to the study of the rich scientific and spiritual heritage of our ancestors, the study of the significant contribution of our scientists to the development of world science and culture and the promotion of scientific heritage has increased. One such scholar is Ubaydullah ibn Mas'ud Sadrush sharia al-Asghar ibn Masud ibn Tajush sharia Mahmud ibn Jamaliddin Ubaydullah al-Mahbubi al-Bukhari. When we study his scientific heritage, we see that in Mowarounnahr not only the science of jurisprudence but also many fields of science such as hadith, puberty, tafsir (elucidation), and literature and so on have developed. "Mukhtasar ul-Vikoya" and his commentary "Sharh ul-Vikoya" in the field of jurisprudence, written during the Mahbubi dynasty, are still widely used by scholars today.

\section{KEYWORDS}

Hidoya, Furuul Fiqh, Khilafah (Contradiction), Jadal (Discussion), and Hadith, Nahv (syntactic), Lughat (Dictionary), Literatire, Ilmi Kalam (Oratory), and Mantiq (Logic).

\section{INTRODUCTION}

The rich culture of our region with an ancient history has been perfected over the centuries by the creativity of our ancestors, who have been masters of science, enriched and risen to the highest levels of development, becoming an invaluable heritage not only for us but for all mankind.

It has always been the dream of the Uzbek people to raise the society to spiritual heights, 
to bring up a perfect person, to lay a solid foundation for the future. In particular, the ideology of national independence of the independence period requires the spiritual maturity of the new generation. From this point of view, after the independence of our country, the attention to the study of the rich scientific and spiritual heritage of our ancestors, the study of the significant contribution of our scientists to the development of world science and culture and the promotion of scientific heritage has increased.

\section{THE MAIN FINDINGS AND RESULTS}

The full name of this imam is Ubaydullah ibn Masud Sadrush sharia al-Asghar ibn Masud ibn Tajush sharia Mahmud ibn Jamaliddin Ubaydullah al-Mahbubi al-Bukhari [1, p. 369].

"Sodrush sharia al-Asghar" means "small sadrush sharia". It is clear from his genealogy that his great-grandfathers also had the nickname Sodrush Shari'a. That is why the great grandfather is called "Sodrush sharia alAkbar" - "Great Sodrush sharia", and the grandson is called "Sodrush sharia al-Asghar" "Little Sodrush sharia". Some sources also distinguish the two as "Sodrush Sharia First" and "Sodrush Sharia Second".

The author lived during the reign of the Mongols in the land of Mowarounnahr, when these cities came under the rule of Genghis Khan in $616 \mathrm{AH}$; they destroyed the whole land, especially Bukhara [2, p. 11]. Ibn Batuta says in this regard: "Bukhara was one of the pillars of Mowarounnahr, and Jaihun became one of the cities destroyed by Genghis Tatars, its mosques, madrasas and markets are now in ruins, only a small part is well preserved, and its people are despised, their testimonies were not accepted in Khorezm or elsewhere. For they testified fanatically in their false claims and in their denial of the truth, yet there was no one among them who knew anything about science or encouraged knowledge".

Then Oktaykhan took over this administration. He was the third child of Genghis Khan and the governor in his time. He succeeded his father to the throne in $624 \mathrm{AH}$. In 636, the people revolted against the Mongols and the kingdom, but this revolt was calmed down. Then, in 671, the Persian Mongols captured Bukhara, and for seven days they destroyed it, the ruins fell to their knees, and this situation was continued for two more years by two emirs, Juba and Qan, in the hands of other emirs. He was both of the Chigatay Turks. Even after them, for 7 years there was no gentle wind in these lands. In 682, Koydmasudbek returned his people to them. In 816, the Persian Mongols invaded again and expelled most of the people and settled them in the regions of Jaihun [3, pp. 110-112].

This was the suffering of Bukhara. As Ibn Batuta reported, the townspeople were forced to leave the land and move to Kerman, where Sodrush spent his youth in Kerman after his grandmother and grandfather also died there.

There is also evidence that Sodrush Shari'a was staying in Herat, but he decided to go to Bukhara because it was the homeland of his ancestors and there are reports that Sodrush Sharia died there.

In the eighth century, according to Herat Ibn Battuta, "The major cities of Khorasan were four, Herat and Naysabur, and the other two were the ruined Balkh and Marv. The city of Herat was large, majestic, with many buildings, and its inhabitants were pious, chaste, and pious people. They belonged to the Abu Hanifa sect and their cities were free of corruption". 


\section{Nickname of Sodrush sharia.}

Also, the nickname Sodrush was mainly used in reference to Ubaydullah ibn Masud [4, p. 278]. Imam Sodrush Sharia Ubaydullah ibn Masud was born and raised in Bukhara in a family where all generations from his ancestors were scholars of science and jurisprudence. When they were born is not mentioned in the sources. The period in which the scientist lived coincides with the Mongol invasion. So at a young age he was forced to flee to the Kerman area with his family. But he continued to learn nonetheless. His ancestors, Mahmud ibn Sadrush, learned the basic sciences from the Shariah.

He has documents that reach Imam Abu Hanifa (may Allaah have mercy on him) and he says:

His grandfather Tajus Sharia Mahmud ibn Sadrush Sharia,

His great-grandfather Ahmad ibn Jamaluddin,

Jamaluddin Ubaydullah al-Mahbubi,

Sheikh Imam Mufti Imamzoda,

Sheikh Imomuddin [5, p. 27].

Ubaydullah ibn Masud was one of the prominent scholars of his time, especially in the sciences such as Usul al-Fiqh, Furuul Fiqh, Khilafah (Contradiction), Jadal (Discussion), and Hadith, Nahv (syntactic), Lughat (Dictionary), Literatire, Ilmi Kalam (Oratory), and Mantiq (Logic).

Students introduce him as Sodrush Sharia in books of jurisprudence and method. Although the nickname Sodrush Sharia was not widely known in those cities in those centuries, it was well known to translators, and the name became a symbol for him. Ibn Battuta narrates about his travels to Khorezm and Bukhara: "He went to the city of Al-Kat, and then the judge of the city of Kat, called Sodrush Sharia, came. I met him in the courtyard of the Khorezm judge with the students". This biography did not belong to him because Ibn Battuta quotes two pages later as evidence that this man is not him. The reason for the use of these names, as the owners of biographical books have pointed out in reprimands, was that the practice was ingrained in the people of Khorasan and Mowarounnahr in distinguishing one person from another. Similarly, Shamsul Aimma, Fakhrul Islam, Sodrul Islam, Sodrul Jahan, Tujush Sharia, Burhanush Sharia, Sodrush Shari'a and so on. But this is against the Iraqi jurists. In them, the nickname is simply a matter of proportion, what you make, the neighborhood, the tribe, the village. Jassos, Quduri, Karkhi, Soymari, this situation has occurred in recent times, but it has not been observed in previous times.

\section{Some scholars deny these nicknames:}

One of them: Qurtubi, in his book Sharhi asmaillahi al-husna, says: "The Book and the Sunnah indicate that a person is forbidden to praise his passion". Our scribes say: "The same work may have multiplied in Egypt, Arabia, and the lands of the non-Arabs. They characterize themselves with qualities that testify to praise and glorification". For example: "Zakiyyiddin (developer of religion), Muhiddin (reviver of religion), Ilmuddin (knowledge of religion) and others" [6, p. 410].

One of them: Ibn Nuhas, in his book "Tanbih alGhafilin", lists the evil deeds and says: "The following are some of the things that are lying about religion: Muhiddin (the one who revives the religion), Nuriddin (the light of the 
religion), Adodidding (the helper of the religion), Ghiyasiddin (the helper of the religion), Muiniddin (the source of the religion), Nasir al-Din (the victor of the religion) similar nicknames. Lies like this are often repeated in languages when calling someone, describing them, and telling a story about them. All this is heresy and repetition in religion".

But Laknavi answers them after narrating them: "Calling with such nicknames does not and does not mean that the person being called is like that. In doing so, he wills to cultivate his passion" [7, p. 410].

\section{About the name of Sohibi "al-Wiqaya"}

The scholars differed greatly on the identity of the owner of "al-Waqiya", even though they agreed that the owner of the book was the grandfather of the younger Sodrush Sharia (Ubaydullah ibn Masud) and the son of the great Sodrush Shari'a. The nickname of the owner of this book was Burhani Sharia. However, the ancestor of the real Sodrush Sharia (Ubaydullah ibn Masud) is the Taji Shariah who interpreted the book al-Hidaya. This is stated in the preface of his book "alWaqiya" by Sodrush Sharia. He said, "But let the servant of Ubaydullah ibn Masud Sadrush, who seeks Allah with the most powerful means, have a great and glorious share in the Shari'ah ibn Tajush Shariah. He says - his "My grandfather and Mawlam, the scholar Rabbani, the factor Somadani, the Sharia, the Burhan of Truth, the successor of the Prophets and the Mursalis, Mahmud ibn Sadrush, on behalf of me and all Muslims, wrote "Wikoatur-riwoya fi masoli Hidoya" to give him good rewards".

The preface to "Al-Tawzih" also states: "May the share of Ubaydullah ibn Masud ibn Tajush Shariah, who seeks Allahu taala by the most powerful means, be great and may his efforts be saved" [ 8, p. 32]. The same thing happens in the introduction to the book Sharhul Wiqaya.

To conclude, the term Sodrush Sharia refers to the Shariah of Tajush, the true ancestor of Ubaydullah ibn Mas'ud. At the same time, he had another grandfather, Burhanush Sharia, who wrote the book "al-Wiqaya" for Ubaydullah. So his statement raises two possibilities.

The first is that the Tajus Sharia is Burhanush Sharia itself and its name is Mahmud. He interpreted "al-Hidaya" because the Hanafi scholars agreed that Tajush interpreted alhidaya in the Shariah. Al-Kafawi made this point in his book Katoibu Alamil Akhbar. The same idea was put forward in the biographies of the Shari'ah of Tajush, Shariah of Sodrush, Ibn Qutlubugha, Ibn al-Hanai, and Tashkabari. At the same time, Murtaza az-Zabidi stated that he had the same opinion in his work "History of Bukhara".

There are several works by Ubaydullah ibn Mas'ud, the most famous of which is "Mukhtasar ul-Wiqaya", which is taught as a textbook in many madrasas. This book is one of the four main texts addressed in the science of jurisprudence, an abbreviation of the book "Wikoatur-riwoya fi masoli Hidoya" written by his ancestors. He also wrote a commentary on this book of his ancestors, which is called "Sharhul Wiqaya". This book is still widely used by scientists today. Sodrush Shari'a has other books such as "At-Tanqih", "At-Tawzih", “AlVishah", "Taadil ul-Ulum”, "Muqaddimat ulArbaa”, "Ash-Shurut val-Mahazir”.

Imam died in $747 \mathrm{AH}$ in Bukhara. All his relatives, except for his two grandfathers, were buried in Bukhara. His two grandfathers died in Kerman and were buried there. 
One of the many commentaries and abbreviations for Hidaya is Mahmud ibn Ahmad al-Mahbubis (4500s) book, "Wikoatur-riwoya fi masoli Hidoya" (Preservation of Narrations on the Issues of Hidaya). Al-Mahbubi, nicknamed "Tojush Sharia" (Crown of Sharia), abbreviated this work from "Hidaya" and wrote it for his student and grandson Ubaydullah ibn Masud al-Mahbubi. Several manuscripts of this work are also kept at the Institute of Oriental Studies.

When Ubaydullah ibn Mas'ud mastered the science of jurisprudence, he shortened the book "Wiqayat ur-Rivaya" written for him by his grandfather and compiled a separate book. He himself writes about this: I, Ubaydullah, removed this Mukhtasar from the "Wiqayat urRivaya" after seeing that the devotion and desire of some scholars was short and helpless to memorize the "Wiqayat ur-Rivaya". Whoever has the time to study science, let him study the story. Whoever has less time, let him memorize "Mukhtasar".

When Ubaydullah finished the "Mukhtasar", he called it "An-Niqaya Mukhtasar ul-Wiqaya" (Selected Abbreviation of the Story).

However, the book became known as "Mukhtasar ul-Wiqaya" or simply "Mukhtasar". Ubaydullah's son Mahmud memorized the "Mukhtasar" compiled by his father and began to write a commentary on his grandfather's book, "Wiqayat ur-Rivaya". Ubaydullah ibn Mas'ud helped his son. However, after Mahmud's death in 1344, the book remained unfinished. His father, Ubaydullah, finished the book in 1346 and called it "Sharhi Wiqaya" (Commentary on the Book of Stories).

The book "An-Niqaya Mukhtasar ul-Wiqaya" became widely known as "Mukhtasar" and served as a basic guide for students of religious sciences. In madrassas, this work was memorized by students. Over the years, "Mukhtasar" began to receive comments. An example is Abul Makarim ibn Abdullah's "Sharhi Mukhtasar ul-Wiqaya". This work was written in 1501, and the manuscript is kept at the Institute of Oriental Studies under the number № 2184 / 1R. A copy of Abdul Ali ibn Muhammad ibn Husayn al-Birjandi's "Sharhi Mukhtasar ul-Wiqaya", copied in 1529, is also kept under the number № $2389 \mathrm{R}$.

Second: Tajush Sharia Sodrush is the ancestor of Shari'a, and he is a commentator on "Hidoya". The names of Burhanush Shariah are Mahmud. Tajush Sharia and Burhanush Sharia are the two sons of the great Sodrush Sharia.

These thoughts were quoted from the Shari'ah in the book "Hidoya Sharkhi" (at the end of the Oath of Allegiance) when the owner of the book "Kashf" quoted the commentators of Hidoya and said, "Abu Abdullah Umar ibn Sadrush completed the benefits of this book of oaths at the end of Sha'ban in $673 \mathrm{AH}$ ".

\section{The genealogy of the owner of "Wiqaya"}

The lineage of the owner of "Wiqaya" goes back to the great companion Ubada ibn Samit. There are those who describe them as Quraysh, Tamimi, Kufi. These views differ on the names of several ancestors, and there are two views on them:

First: Sahib al-Wiqaya is the son of the great Sodrush Shariah Ahmad ibn Ubaydullah ibn Ibrahim ibn Ahmad ibn Abdulmalik ibn Umar ibn Abdulaziz ibn Muhammad ibn Jafar ibn Marwan ibn Muhammad ibn Ahmad ibn Mahbub ibn Walid ibn Ubaida ibn Samit Ubadi Mahbubi Bukhari Hanafi. 
Second: Sahibul Wiqaya is the son of the great Sodrush Shariah Ahmad ibn Jamaliddin Abul Makarim Ubaydullah ibn Ibrahim ibn Ahmad ibn Abdulmalik ibn Umayr ibn Abdulaziz ibn Muhammad ibn Jafar ibn Khalif ibn Harun ibn Muhammad ibn Muhammad ibn Mahbub ibn Walid ibn Ubada ibn Samit Sahib Ansari Mahbubi [9, p. 84].

\section{The words of the scholars about the confusion about the genealogy of Sodrush Shariah:}

The conclusion of the narrations about the genealogy of Sadr al-Sadr is as follows:

Ubaydullah ibn Masud ibn Umar Tajush Sharia ibn Ahmad ibn Sadrush sharia Al-Akbar ibn Ubaydullah Jamaliddin Abu Al-Makarim ibn Ibrahim ibn Ahmad to Ubaida ibn Samit.

1. One of them: It is narrated on the authority of Qasim ibn Qutlubu that Mahmud ibn Ubaydullah ibn Mahmud. Ubaydullah was called the son of Mahmud, although they were his grandfathers and their father was Ahmad. Ubaydullah's father was called Mahmud, although his father's name was Ibrahim.

2. One of them: Tashkabri exaggerated by reciting the lineage like Kutlubgo and relied on their words, and their answers were the same as their answers. He added: "Sadr Sharia is Ubaydullah ibn Mahmud ibn Muhammad Al-Burhani". Mahmud ibn Muhammad is the father of Ubaydullah, and it is true that their father is Masud ibn Umar, and his lineage goes to Burhani, a ratio that has not been heard of, and that is what the last scholars were called by this lineage.

3. One of them: Quhistani said: "Umar ibn Sadrush is the Shari'ah of Ubaydullah ibn Mahmud ibn Muhammad" [10, p. 33]. In this view, Ubaydullah turns out to be the father of Umar. He is also the father of Mahmud ibn Muhammad Ubaydullah. The most correct statement is that of Ubaydullah's father, Ibrahim ibn Ahmad. And again, Mahmud ibn Sadrush is Ubaydullah ibn Mahmud ibn Muhammad in the Shariah. In this regard, the Great Sodrush Sharia - Abdullah and he is the father of Mahmud. It is true that the Great Sodrush is Ahmad according to the Shariah, and Ubaydullah is the grandfather of Mahmud. He is also the father of Mahmud ibn Muhammad Ubaydullah. The truth is that Ibrahim ibn Ahmad was the father of Ubaydullah.

\section{CONCLUSION}

To conclude, Ubaydullah ibn Masud Sodrushs scholarly legacy is a textbook of jurisprudence in these madrassas because it answers today's most pressing questions, embodies a culture of morality, and is written in a simple and concise manner. In particular, the texts of "Mukhtasar ul-Wiqaya" are memorized by students. As we remember our great ancestors, it is the duty of all of us to be a suitable generation for them, to study their scientific heritage more deeply.

\section{REFERENCES}

1. Abdulkadir ibn Muhammad al-Qurshi. (2008) Al-Jawahir al-Maziya fi Toboqot alHanafiya: Vol. 4. - p. 369.

2. Introduction to History Bukhara. - p.11.

3. Muhammad Abdulhay al-Laknavi. (1998) AlFavaid al-Bahiyyat fiy Tarojim al-Hanafiyya. - pp. 110-112

4. Kitabu alam al-Ahbor. - p. 278.

5. Abdullah ibn Masud al-Mahbubiy al-Hanafi. (2006) Sharh ul-Wiqaya. - p. 27. 
6. Muhammad Abdulhay al-Laknavi. (1998) Alfavaid al-Bahiyyat fiy Tarojim al-Hanafiyya. - p. 410.

7. Muhammad Abdulhay al-Laknavi. (1998) AlFavaid al-Bahiyyat fiy Tarojim al-Hanafiyya. - p. 410.

8. Abdullah ibn Masud al-Mahbubiy al-Hanafi. (2006) Sharh ul-Wiqaya. - p. 32.

9. Abdul Mawla Dimyoti. Taliqul anwar alad darril Mukhtasar. - p. 84.

10. Abdullah ibn Masud al-Mahbubiy al-Hanafi. (2006) Sharh ul-Wiqaya. - p. 33. 